\title{
Production and Application of Biosurfactants in Biotechnology
}

\author{
Fatemeh Shakeri ${ }^{1}(\mathbb{D})$, Hamid Babavalian 1,* ${ }^{\mathbb{D}}$, Mohammad Ali Amoozegar ${ }^{2}{ }^{\mathbb{D}}$, \\ Zeynab Ahmadzadeh ${ }^{3}$ (D), Sahar Zuhuriyanizadi 4 (D), Mahsa Pahlevan Afsharian 4 (D) \\ Applied Biotechnology Research Center, Baqiyatallah University of Medical Sciences, Tehran, Iran \\ 2 Extremophiles Laboratory, Department of Microbiology, Faculty of Biology and Center of Excellence in Phylogeny of \\ Living Organisms, College of Science, University of Tehran, Tehran, Iran \\ 3 Department of Microbiology, School of Biology, University College of Science, University of Tehran, Tehran, Iran \\ 4 Extremophiles Laboratory, Department of Microbiology, School of Biology and Center of Excellence in Phylogeny of \\ Living Organisms, College of Science, University of Tehran, Tehran, Iran \\ * Correspondence: h.babavlian@yahoo.com;
}

Scopus Author ID 36730727200

Received: 27.09.2020; Revised: 20.10.2020; Accepted: 22.10.2020; Published: 26.10.2020

\begin{abstract}
Biosurfactants possess both hydrophilic and hydrophobic areas and are generated on the microbial membrane or excreted over the outer membrane. Amphipathicity leads to reduce strength and interfacial tension between the individual molecules on the surface and the two-state immiscible sector. Regarding the low critical micelle concentration (CMC) and high surface activity, biosurfactants can be effective alternatives to their synthetic equal one. Plant-based oils and fats are used in biosurfactants production. Many wastes are produced by the oil and grease industries, tallow, residual oils, marine oils, soapstock, burnt oils, and Manipura. The operation of industrial fatty acid excesses is promising for expansion and transformation. Via making various substances like olive oil mill, acid, whey, and molasses, the agro-industry can ease biosurfactant creation. Biosurfactants have many advantages over chemical production, involving capable of decomposition higher by bacteria or living organisms, less poison, environmental concordance, higher foaming, and the rate of its selection is higher. They can also adjust to the highest salinity, $\mathrm{pH}$, and temperatures and can be produced out of renewable materials, resulting in an increased demand for biosurfactants. Bioemulsifiers and biosurfactants (BSs) have various applications and are a considerable character in many industrial fields, as well as biotechnological features, including pollutant biodegradation, microbial enhanced oil recovery (MEOR), and pharmaceutics. This review the latest information and improvement in biosurfactant application and development for more output and future applicability.
\end{abstract}

Keywords: microbial surfactant; CMC; surface tension; oil recovery.

(C) 2020 by the authors. This article is an open-access article distributed under the terms and conditions of the Creative Commons Attribution (CC BY) license (https://creativecommons.org/licenses/by/4.0/).

\section{Introduction}

Biosurfactants are bio surface-active agents which are produced via numerous microorganisms $[1,2]$ and highly requested of the market regarding their distinctive ecofriendly characteristic. As the discovery of purified biosurfactant, which has known as a surfactin, they have greatly increase examining some of their features revealed that they are not very desirable in most aspects of human life. At present, so-called synthetic substances that the main ingredients are oil, are most in demand. Most of these compounds are detrimental material and non-decomposable [3]. Since they are involved in bioaccumulation, their performance, yield, and by-products may have serious environmental consequences. Strict 
laws were passed to protect the environment; thus, the replacement of chemically produced surfactants with biosurfactants is crucial [4]. In a different subject, biosurfactants are known as high-efficiency molecules. They are widely used in studies of hydrocarbon bioremediation and increase retrieving the oil from the well (EOR) [5]. Universally, 17 MMT surfactants (with soaps) were produced at future pace increases of 3-4\% per annum. On the other hand, 1.5-2.0\% of various surfactant applications in the EU depend on their usage [6]. In addition, the exclusive feature of biosurfactant leads to efficient use in agriculture $2 \%$, chemical processes $10 \%$, cleaners, and detergents $54 \%$, cosmetics, and pharmaceuticals $3 \%$, food industry $3 \%$, leather and paper $10 \%$, textiles $13 \%$, and other items are $8 \%$, thus gaining a good position. However, most compounds are still being produced during the chemical process from hydrocarbons, albeit surface-active molecules of an organism (i.e., biosurfactants) have gained remarkable attention in recent years. Biosurfactants possess both hydrophilic and hydrophobic areas produced on the microbial membrane or excreted across the outer membrane. Amphipathicity leads to decrease strength and interfacial tension between the individual surface molecules and the two-state separate part (Fig 1) [7, 8]. They have numerous industrial and environmental features concerning emulsification to form foam, detergency and dispersal, wetting, bioremediation, MEOR, and hydrophobic soluble compounds [5].

Biosurfactants are not harmful to the environment and less poison, rendering them decomposable compared to chemically produced surfactants. Additionally, high foaming, carefully choosing something most suitable, and certain potency, an extensive range of capabilities and renewable feedstocks in the production approach are distinctive merits of biosurfactants that could be derived [9]. These compounds reduce interfacially and surface tension in hydrocarbon mixtures and water solutions [10], hence making them a potential possibility for EOR [11] and the emulsification process [12]. Ascribe a high price market to the expansion of biosurfactants [13], complicated procedures of pure substance collection, rare microbial strains (low product concentration capability for those generally found). Biosurfactants have lately attracted much attention due to their high capacity in industrial and environmental operations. Biosurfactants are vital as a consequence of antimicrobials features, biofilm infraction, food industry, healthcare, to eliminate heavy metal, decomposition of hydrocarbon, MEOR, and quorum-sensing (QS). Biosurfactants are excreted by plenty of microorganisms, such as bacteria, fungi, yeast, and actinomycetes exterior of the cell. The majority of them are synthesized by bacteria. Microbial surfactants are indeed lipid molecules whose occurrence, possession, and chemical structure have been extensively investigated in some cases such as antibacterial activities, etc. They are only produced during the growth of microorganisms on hydrophobic substrates [14]. Bacillus salmalaya, Candida lipolytica, Pseudomonas aeruginosa, Saccharomyces lipolytica, Rhodococcus, and Corynebacterium are some microorganisms of this type. Another class of surfactants is both water-soluble and hydrophobic, including Pseudomonas aeruginosa and Torulopsis bombicola. Hence, the composition and nature of the substrate must be measured to select the appropriate microorganisms [5]. In this review, the latest approaches in knowledge about biosurfactant applications and biotechnological strategies were being examined and expanded for better output of various aspects. 


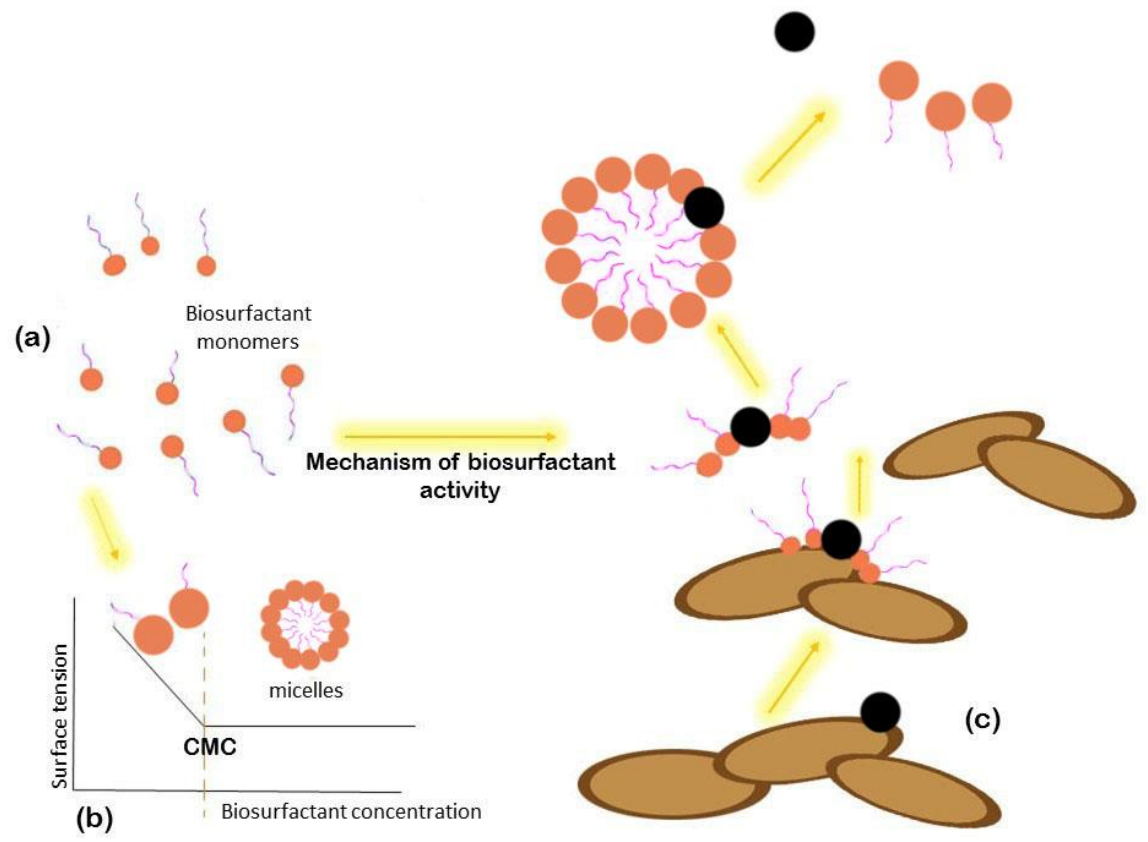

Figure 1. a) Biosurfactant monomers; b) Critical micelle concentration or CMC; c) Mechanism of biosurfactant's activity.

\section{Potential commercial applications}

All surfactants are synthesized chemically. Nevertheless, ample thought has been newly directed toward biosurfactants. They have been preferred over artificial surfactants attribute to their broad capabilities, the synthetic capacity of biodegradable microbes, and lower toxicity. Some of the industrial properties of biosurfactants have been predicted [15].

\subsection{Oil industry.}

Multi-biotech, a secondary technology from Geodyn, has commercialized biochemical pharmacology for better use in oil recovery. Bacillus licheniformis JF-2, collected from the accumulation of water injected into the oil field, synthesizes most promising biosurfactants (CMC, $10 \mu \mathrm{g}-1$, the interfacial tension of the salt-decane interface, which decreases to 3-10 dynes cm-1). It has other benefits as well, such as being halotolerant, thermotolerant, and anaerobic, propounding them a potential compound in MEOR $[11,16]$.

\subsection{Heavy metal-binding.}

Certain biosurfactants like rhamnolipids are capable of extracting the number of the component from the soil, such as $\mathrm{Pb}, \mathrm{Zn}$, and $\mathrm{Cd}$. Rhamnolipids can reduce the poison of metal by using $\mathrm{Cd}$ complexation and their interactions with the cell surface to modify $\mathrm{Cd}$ uptake. High-molecular-weight (HMW) of polysaccharides in emulsifiers interact with metals through linking them, as noted for uranium connecting by the emulsifier Acinetobacter calcoaceticus [17].

\subsection{Food industry.}

Biosurfactants have numerous thriving qualities in the food industry as a food supplement. Fatty acid esters (FAEs), including sorbitan or ethylene glycol, glycerol, lecithin, and its derivatives, and the producer of ethoxylated monoglycerides (EMGs) involving 
manufactured oligopeptides are now used as emulsifiers in the food business around the world [15].

\subsection{Cosmetic industry.}

Many substances are synthesized for practical cosmetic usage. For illustration, Whole cells and various lipases utilize for the enzymatic transformation of hydrophobic molecules. Biosurfactants, the ones appropriate for cosmetics, should have at least three years to remains usable. Thus, saturated acyl groups are desire over unsaturated monoglycerides. Surfactants are mostly utilized in cosmetics for creating glycerol from tallow (1.5:2) using the lipase from Pseudomonas fluorescens (usage percentage $=90 \%$ ) [18].

\subsection{Pharmaceutical industry.}

Prematurely neonatal have respiratory issues related to the lung surfactant, which can validate normal using a protein-phospholipid complicated (PPC). This protein can have medicinal properties due to fermentative production by cloning the corresponding genes to bacteria. Tobacco mosaic virus (TMV), mainly from Nicotiana glutinosa) and potato virus X (PVX) can be treated and controlled by 1\% rhamnolipid emulsion [19].

\subsection{As emulsifiers.}

Biosurfactants can assist the emulsification of water/hydrocarbon mixtures, that this is the section that is well investigated. They have been shown to heighten hydrocarbon decomposition, supply them applicable in managing oil spills [19].

\subsection{Peat dewatering.}

Surfactin has proved to fetch in mechanical dewatering in a particular volume of space is below $13 \mathrm{~g}$. ton-1 [11].

\section{Properties of biosurfactants}

Several properties of biosurfactant are lessening surface tension, foaming capacity (FC), emulsifying (EC), stabilizing capacity, reducing CMC, solubility and detergency. These physicochemical features of biosurfactants are crucial in estimating the proficiency and selection of microorganisms that are responsible for the generation of biosurfactants [20]. Despite various chemical constituents and properties, multiple characteristics are common to the majority of biosurfactants, many of which suggest its primacy over ordinary surfactants [13].

\subsection{Surface and interfacial activities.}

At a diminished mass, biosurfactants yield less surface tension, show greater potency and productivity compared to prosaic surfactants. CMC of biosurfactants (competence measurement) varies from 1 to $2000 \mathrm{mg} / \mathrm{l}$, while surface and interfacial tension (oil/water) are rough 1 and $30 \mathrm{ml} / \mathrm{m}$ in the order [21]. 
3.2. Many biosurfactants can operate in extreme conditions.

Lipopeptides from Bacillus licheniformis JF-2 sustain its stability at temperatures around $75^{\circ} \mathrm{C}$ for $140 \mathrm{~h}$ within a $\mathrm{pH}$ series of 5 to 12 . Biosurfactants also endure salt concentrations of up to $10 \%$, while $2 \%$ of salt is adequate to inoperative chemically produced surfactants [21].

\subsection{Biodegradability.}

Biosurfactants are degradable by bacteria and other microorganisms in water or soil, enable them sufficient for bioremediation and waste treatment purposes [22].

\subsection{Low toxicity.}

Biosurfactants are now highlighted as a consequence of rising apprehension over the allergenicity of synthetic products [22]. Biosurfactants can also be easily used in cosmetic, pharmaceutical, and food products, an account of their reduction of the poisonous [23].

\subsection{Availability.}

Biosurfactants are a host of applications as they have been produced from industrial waste and raw compounds [24].

\subsection{Specificity.}

As complex organic molecules (COMs) with their functional groups, biosurfactants have particular functions, an issue of considerable interest through detoxification of specific contaminants, as well as application in cosmetics, pharmaceuticals, and foodstuff [25].

\subsection{Biocompatibility and digestibility.}

Biocompatibility and digestibility lead to the employment of biosurfactant in the cosmetic, pharmaceutical, and food industry. On the contrary, Biosurfactants have limitations, too, in a case, mass-produce has a high cost. However, this can dominate when cheap substrates are combined [26]. It is difficult to develop high-purity product extracts since metabolic broth purification requires taking several steps. Highly productive species are scarce and beneficial. Known species in this field cannot produce high surfactant extract and need a complex culture medium. Biosurfactants are biological molecules that probably to be made as a secondary metabolite or in connection with microbial growth; moreover, manipulating the procedure of biosurfactant's procedure is remaining enigmatic. Increasing productivity is often hampered by foam formation, requiring a dilute medium [1].

\section{Types of biosurfactants}

Chemically synthesized surfactants are organized to establish their polar grouping. In contrast, biosurfactants are principally organized by their microbial source and chemical constituents. Their composition generally consists of a hydrophilic moiety of amino acids or peptide cations or anions, monosaccharides, disaccharides, or polysaccharides, and a hydrophobic compound is embracing saturated, unsaturated, and fatty acids. As a result, the main classes of biosurfactants are proceeding. There are various types of biosurfactants like 
Glycolipids, Rhamnolipids, Trehalolipids, Sophorolipids, Lipopeptide, and Lipoprotein, Fatty Acids, Phospholipids, and Neutral Lipids, Polymeric (Table 1) [27].

Table 1. Main classes of biosurfactants and respective producer microorganisms.

\begin{tabular}{|c|c|c|}
\hline \multicolumn{2}{|c|}{ Class/type of Biosurfactant } & Microorganism \\
\hline \multirow{7}{*}{ Glycolipids } & Rhamnolipids & $\begin{array}{l}\text { Pseudomonas aeruginosa, Pseudomonas, Chlororaphis, Serratia , } \\
\text { Rubidea }\end{array}$ \\
\hline & Sophorolipids & $\begin{array}{l}\text { Torulopsis bombicola, } \text { T. antarctica, Torulopsis petrophilum } \\
\text { C. botistae, C. apicola, } \text { C. riodocensis, } \text { C. stellata, } \text { C. bogoriensis }\end{array}$ \\
\hline & Trehalolipids & $\begin{array}{l}\text { Rhodococcus erythropolis, Mycobacterium sp. Arthrobactersp., Nocardia } \\
\text { erythropolis, Corynebacterium sp. }\end{array}$ \\
\hline & Cellobiose lipids & Ustilagomaydis \\
\hline & Mannosylerythritol lipids & Candida antarctica, Kurtzmanomyces sp., Pseudozyma Siamensis \\
\hline & Glycolipid & Streptococcus thermophiles \\
\hline & Diglycosyldiglycerides & Lactobacillus fermentum \\
\hline \multirow{16}{*}{$\begin{array}{l}\text { Lipopeptides } \\
\text { and } \\
\text { lipoproteins }\end{array}$} & Peptide-lipid & Bacillus licheniformis \\
\hline & Streptofactin & Streptomyces tendae \\
\hline & Viscosin & Pseudomonas fluorescens, Leuconostoc mesenteriods \\
\hline & Serrawettin & Serratia marcenscens \\
\hline & Surfactin & Bacillus subtilis \\
\hline & Subtilisin & Bacillus subtilis \\
\hline & Gramicidin & Bacillus brevis \\
\hline & Polymyxin & Bacillus polymyxia \\
\hline & Serrawettin & Serratia marcescens \\
\hline & Polyol lipids & Rhodotorula glutinis, $R$. graminis \\
\hline & $\begin{array}{l}\text { Ornithinelipids, lysine } \\
\text { peptides }\end{array}$ & $\begin{array}{l}\text { Pseudomonas sp., Thiobacillus, thiooxidans, Agrobacterium } \\
\text { Streptomyces sioyaensis, Gluconobactercerinus }\end{array}$ \\
\hline & Pumilacidin & Bacillus pumilus \\
\hline & Iturin & Bacillus subtilis \\
\hline & Sulfonylipids & T. thiooxidans, Corynebacterium alkanolyticum \\
\hline & Lichenysin & Bacillus licheniformis \\
\hline & Arthrofactin & Arthrobacter sp., Corynebacterium sp. \\
\hline \multirow{3}{*}{$\begin{array}{l}\text { Fatty acids, } \\
\text { neutral lipids } \\
\text { phospholipids }\end{array}$} & Fatty acid & $\begin{array}{l}\text { Corynebacterium lepus, Capnoytophaga } \text { sp. Penicillium spiculisporum } \\
\text { Arthrobacter paraffineus } \\
\text { Talaramycestrachyspermus, Norcadia erythropolis }\end{array}$ \\
\hline & Neutral lipids & Nocardia erythropolis \\
\hline & Phospholipids & Thiobacillus thiooxidans \\
\hline \multirow{6}{*}{$\begin{array}{l}\text { Polymeric } \\
\text { surfactants }\end{array}$} & Emulsan & Acinetobacter calcoaceticus \\
\hline & Biodispersan & Acinetobacter calcoaceticus \\
\hline & Liposan & Candida lipolytica, $C$. tropicalis \\
\hline & Carbohydrate-lipid-protein & Pseudomonas fluorescens, Debaryomyces, Polmorphus \\
\hline & Mannan-lipid-protein & Candida tropicalis \\
\hline & Protein PA & P.aeruginosa \\
\hline \multirow{5}{*}{$\begin{array}{l}\text { Particulate } \\
\text { surfactant }\end{array}$} & Vesicles\& fimbriae & Acinetobacter calcoaceticus, P.marginilis, P. Maltophila \\
\hline & Whole Cells & Various bacteria such as Cyanobacteria \\
\hline & Alasan & A. radioresistens \\
\hline & Particulate surfactant $(\mathrm{PM})$ & Pseudomonas marginalis \\
\hline & Biosur PM & Pseudomonas maltophilia \\
\hline
\end{tabular}

\section{Colloidal properties of some biosurfactants}

The CMC (efficiency measurement) varies from 1 to $2000 \mathrm{mg} / \mathrm{l}$, whilst surface tension and interfacial tension (oil/water) are approximately 1 and $30 \mathrm{ml} / \mathrm{m}$, in order. Insufficient expertise about biosurfactants' $\mathrm{CMC}$ is the cause to be a challenging issue to interpret or correlate. Table 2 compares the CMC of biosurfactants. The CMCs for the previous group is much lower. A lower CMC originally suggests a more efficient surfactant, cause to be proper for industrial administration [28]. 
Table 2. Illustrates some examples of the CMC of certain biosurfactants and chemical surfactants.

\begin{tabular}{l|l|l} 
Surfactant & CMC $(\mathbf{m g} / \mathbf{L})$ & Surface tension \\
\hline Phosphatidylethanolamine & 30 & $25 \mathrm{mN} / \mathrm{m}$ \\
\hline Sorphorolipid & 150 & $30-35 \mathrm{mN} / \mathrm{m}$ \\
\hline Rhamnolipid & 20 & $24 \mathrm{mN} / \mathrm{m}$ \\
\hline Surfactin & 11 & $27 \mathrm{mN} / \mathrm{m}$ \\
\hline Emulsan & $25-58$ & $2-10 \mathrm{mN} / \mathrm{m}$ \\
\hline Sodium lauryl sulfate & 8.2 & $55 \mathrm{mN} / \mathrm{m}$
\end{tabular}

\section{Application of biosurfactants in microbial-enhanced oil recovery}

Biosurfactants are one of the most promising substances in MEOR. They are employed to recuperate residual oil in the tank after the main (i.e., mechanical) and secondary (i.e., physical) recovery $[11,29]$. EOR is a vital third operation during which microorganisms or their metabolites, like acids, biomass, biopolymers, biosurfactants, enzymes and gases, and solvents, are utilized to recuperate secondary oil from drained sediments. The residual oil is often situated in hardly accessible regions of the pool where the oil gets stuck in the pores by linear force. Interfacial tension can be reduced using biosurfactants in oil/rock and oil/water mode, thereby, via the reduction in linear forces, restrict oil from moving via the orifice. To form an emulsion, biosurfactants can also link strongly with the oil/water interface. This fixes the oil desorbed in the water and eliminates it by injecting water in the laboratory, which examines the strategy of recuperation crude oil from a water-saturated column. This involved the required substrate (normally sand), which is utilized to prove the productivity of biostructures in oil recuperate. For further research, the reader is referred to as the surfactant yield. Biosurfactants have other administrations in the oil industry [22]. The demulsifying features of some biosurfactants can be exploited for emulsion breakdown that appears in different phases of petroleum extraction and procedures, allowing greater yield recovery. Distinct oil from the bottom of tanks can be accrued by microbial surfactants that decrease surface tension [30]. Despite some field tests in the literature, yet it is not clear whether microorganisms involved are effective in the oil recuperate operation or whether they contend with autochthonous bacteria [29].

\section{Production of biosurfactant}

Biosurfactants have been developed by several researchers using a variety of carbon roots and microorganisms [31]. Carbohydrates, vegetable oils, and hydrocarbons are a notable example that is employed as the origin of carbon to synthesize biosurfactants. From a financial point of view, biosurfactants are in a disparity with surfactants [5]. Other sources of carbon, including olive oil wastewater (OOW), whey from the production of cheese and cassava flour, vegetable oils, molasses (by-products) are not appropriate for applying in the industry [32]. Manufacturing process by some bacteria such as Bacillus sp. isolates using molasses, whey, and manipueria as a substrate to produce biosurfactants from $P$. aeruginosa mutant obtained by accidental mutagenesis with N-Methyl-N-nitro-Nitrosoguanidine [32].

\subsection{Biosurfactant production by the newly isolated and hopeful strain Pseudomonas putida} $21 B N$.

As a kind of biosurfactant, rhamnolipids are generally excreted by Pseudomonas sp. that are amphiphilic, active glycolipids compounds on the surface [33]. 


\subsection{Mannosylerythritol lipids [18] produced by Candida antarctica as a surface-active.}

Lin et al. (X) studied lipopeptides produced by Bacillus licheniformis mutant by $\mathrm{N}$ methyl-N,-N-nitrosoguanidine-mediated accidental mutagenesis [34]. Makkar et al. (X) reviewed the creation of lipopeptide biosurfactant by two strains of the genus Bacillus with employing molasses in a thermophilic situation [35]. It can be exchanged for microbial enhancement and biosurfactant yield consisting of agro-industrial by-products, peat hydrolysate, and urban disposals [36]. Maugard et al. (X) examined the transesterification of fatty acid methyl esters (FAME), and various amines lead to the production of amide surfactant [37]. Kim et al. (X) explored biosurfactants creation by Bacillus subtilis C9 by applying a carbohydrate (the origin of the carbon). Concurrently a hydrocarbon substrate inhabited the biosurfactant yield, lipopeptide biosurfactant emulsified hydrocarbons, crude oils, and vegetable oils [38]. Osman et al. (X) studied Rhamnolipid's products, a multifunctional glycolipid biosurfactant, and pyocyanin, a phenazine produced dye by Pseudomonas strain BOP100 from ethanol as a single source of carbon [33]. Ochsner et al. (X) checked biosurfactant production induced by $P$. aeruginosa. It is associated with high amounts of biosurfactant of rhamnolipid, which is completely replied to the environmental situation [39]. Biosurfactants are produced by applying OOW as a source of carbon by Pseudomonas sp. Nevertheless, peat pressed, urban wastes, and agro-industrial consequences, such as acid whey and OOW, are candidates for biosurfactant yield and microbial growth [40].

\subsection{Halophilic bacteria production of biosurfactant.}

Halophiles (halophilic or salt-loving microorganisms) are significant regarding their essential features of high salt concentrations for growth. They have matured physiologically and genetically to grow and progress under hypersaline state [41-44]. After Larsen [45] and Kushner [35], due to their salt subservience and tolerance, these organisms have been recognized to be light, medium, and severe halophiles [46]. Most halophiles inhabit hypersaline waters and soils, salt or salt deposits, and salt products [46, 47]. Multi reservoir solar salterns represent general thalassohaline water systems with salinities from seawater salinity to rock salt saturation that are associated with changes in microbial community characteristics [48]. Similarly, aerobic, anaerobic, and facultative anaerobic microbes that belong to Archaea and Bacteria, which are recovered through a thalassohaline waters of the Dead Sea, Salt Lake, the hypersaline lakes in Antarctica, Lake Magadi [49]. Many researchers have reported polysaccharides secreted from haloarchaea and halobacteria, and a constituent of the genus Halomonas have been detected as feasible producers [8, 10]. The features of extracellular polysaccharide in halobacteria have been expanded, and their possible administration has been highlighted for the last few years. The principal creator of extracellular polysaccharides (EPSs) reported to date has been recognized by members of the families Alteromonadaceae and Halomonadaceae. Members of the genus Halomonas, the most typical medium-sized halophilic bacteria, have been designated as a feasible creator of EPS that synthesize various polymers of various physical and chemical characteristic [50,51]. Some of the EPS-producing microorganisms are Alteromonas hispanica strain F32T, Halomonas alkaliantarctica strain CRSS, H. alkaliphila, $H$. almeriensis, H. anticariensis, $H$. eurihalina F2-7, $H$. eurihalina Al12, H. maura S-30, and H. rifensis [50]. 


\section{Biosurfactant extraction, purification, and characterization}

Biosurfactant purification can be mediated via solvent extraction [52]. First, for obtaining cell-free supernatant (CFS), there is a need to centrifuge at $4^{\circ} \mathrm{C}$ for $20 \mathrm{~min}$. Second, utilize $6 \mathrm{~N} \mathrm{HCl}$ to obtain $\mathrm{pH} 2.0$ and then extract twice with an equal proportion of relaxed ethyl acetate [53]. Subsequently, via the rotavap, transform the liquid to gas shape, therefore absorb the oil which remains yellow and wash with $\mathrm{ddH}_{2} \mathrm{O}$. In the next step, purify and lyophilize, respectively. The biosurfactant which lyophilizes conduct by thin-layer chromatography (TLC) and then remove and apply for the adsorption chromatography on silica gel. The compounds which purified in advance should identify via phase conversion of HPLC with SPD-20A/20AV UV-Vis system (Shimadzu HPLC LC-2010AHT) and C18 column (4.6mm×250mm). The dried $\mathrm{KBr}$ pellet sample analyzes by utilizing a Fourier-transformed infrared (FT-IR) spectrophotometer (PerkinElmer $580 \mathrm{~B}$, USA) in a spectrum range of $5000-400 \mathrm{~cm}^{-1}$ using an intuitive software interface Spectrum 10 to collect spectral data. The water (D2O) analyze in the Bruker JNM-A500 spectrometer (Bruker BioSpin AG, Switzerland) at $400 \mathrm{MHz}$ [53]. Biosurfactants that extracted from CFSs through Folch's extraction method employ for lipid extraction from biomolecules. Folch's extraction method was described in other articles [53].

\section{Degradation pathway}

Presumably, many bacteria growing on alkanes mediate the increased active effect of PAHs by producing biosurfactants to help resolve PAHs. For instance, the produced biosurfactant by $P$. aeruginosa growing on naphthalene or phenanthrene has been proved to increase the apparent solubility of these PAHs [54]. It appears that natural surfactants increase the deletion of PAHs from the soil by enhancing the PAH solution, thereby raising PAHmicrobial interactions [55]. Surfactant-enhanced remediation [39] has been used extensively in PAH-poison soil [56]. Bioremediation persuade by microbial decomposition is often used; natural and affordable materials help as supportive matrices for this method to be promising. Bio-decomposition research has highlighted the storage of isolated bacteria to strengthen the bacterial population, followed by an enhanced in the PAH bio-decomposition product. Nonetheless, there are a few studies on the inoculation-based increased effectiveness of isolated bacteria [57]. Various microorganisms such as algae, bacteria, or fungi have potent to be selected for PAH biodegradation [58-60]. The microorganism-induced PAH biodegradation is subject to a large number of excellent studies [22, 61]. The biodegradation of tricyclic PAH compounds (i.e., low molecular weight (LMW)) has been well studied. LMW PAHs are more degradable than their HMW counterparts [22]. Microbial PAH degradation occurs in three modes: complete mineralization, co-metabolic transformation, and non-specific oxidation [62, 63]. Another form of biodegradation is PAH biodegradation through aerobic microorganisms. For effective disinfection of contaminated areas, it is a good idea to have complete mineralization to prohibit the accumulation of metabolites. The complete mineralization of several PAHs has been identified for some bacterial strains associated with various phylogenetic classes [61].

There are two major PAH degradation mechanisms, reliant upon available oxygen. In the aerobic aromatic catabolism, oxygen serves both as the terminal electron acceptor and the co-substrate for hydroxylation and oxygenolytic ring cleavage of the aromatic ring. Conversely, anaerobic aromatic catabolism attacks the aromatic ring using a distinct strategy, mainly based on redox reduction [9]. Aerobic aromatic catabolism has undergone extensive 
studies, yet anaerobic aromatic degradation research has recently discovered a microbial capacity that is still awaiting an in-depth understanding. Nevertheless, oxygen conditions prevail in many natural and contaminated sites (e.g., submerged soils, aquatic sediments, and aquifers) that are replaced by anaerobic biodegradation using terminal electronic acceptors, such as nitrate, sulfate, or iron ions [64]. Bacteria can induce PAH degradation via the cytochrome P450-mediated pathway as well, with the production of trans-dihydrodiols [65]. or under anaerobic (i.e., nitrate-reducing) conditions [66].

\section{Enzymatic degradation mechanisms}

Bacteria can cause remediation or degradation to environmental risks through achieving energy sources from almost any compound and have evolved as the ultimate nature over three billion years ago [28]. For PAH decomposition, different bacteria have been discovered, most studied in the naphthalene and phenanthrene decomposition area. Many distinctive metabolic pathways for bacterial PAH decomposition have been well substantiated in several good review articles $[67,68]$. PAH can be degraded by some specimens isolated from soil or sediments and a large number of general bacterial species [69]. PAHs in the soil are decomposed by bacterial strains, depending on classified groups such as Sphingomonas, Burkholderia, Pseudomonas, Mycobacterium, sphingomonads, Sphingobium, Burkholderia fungorum, Novosphingobium, and Sphingopyxis [70]. The biochemical pathway of bacterial degradation of LMW PAHs, such as phenanthrene, naphthalene, and anthracene, has been reported [20]. Enzymes involved in PAH decomposition include dehydrogenase, ligninolytic enzymes, and oxygenase. Fungal ligninolytic enzymes include laccase, manganese peroxidase, and lignin peroxidase [54]. Basidiomycete-producing laccases are enzymes that contribute to xenobiotic decomposition. In this study, they were combined to provide an industrial expression operation related to Lentinula edodes laccases, determining their enzymatic attribution and estimating their bioremediation competence [71]. Gene models were used to clone the two alleles of the 1573 alkaline lactase alkali from $L$. edodes L54 based on the genome sequence [72]. An alternative laccase-specific signature sequence was introduced by the new upstream consensus (GCTCCGA/CCGGAG). The two alleles were overexpressed in Pichia pastoris, purified, and confirmed by zymography. The kinetic analysis offered a catalytic output order, i.e., 2,2'-azinobis (3-ethyl benzothiazoline- 6-sulfonic), 2,6-Dimethoxyphenol, Guayaquil, L-3,4 dihydroxyphenylalanine, Catechol, and a constant operating temperature range as low as $40^{\circ} \mathrm{C}$. Using convenient mediators of 1-hydroxy benzotriazole and 2,2,6,6-tetramethylpiperidine-1oxyl, recombinant enzymes can mediate the catalysis of a 70-100\% decolorization of the dyes selected and anthracene degradation. These results provide a sound basis on which $L$. edodes laccases are used in bioremediations and advances in protein engineering. Table 3 shows the PAH-degrading microorganisms [73].

Table 3. The PAH-degrading microorganisms.

\begin{tabular}{|c|c|c|c|}
\hline An enzyme (s) & PAH(s) & $\begin{array}{l}\text { Degrading } \\
\text { microorganisms }\end{array}$ & Reference \\
\hline Soluble methane monooxygenases & $\begin{array}{l}\mathrm{C}_{1}-\mathrm{C}_{8} \text { alkanes alkenes and } \\
\text { cycloalkanes }\end{array}$ & $\begin{array}{l}\text { Methylococcus sp., } \\
\text { Methylosinus sp., } \\
\text { Methylocystis sp., } \\
\text { Methylomonas sp., } \\
\text { Methylocella sp. }\end{array}$ & [74] \\
\hline Particulate methane monooxygenases & $\begin{array}{l}\mathrm{C}_{1}-\mathrm{C}_{5} \quad \text { (halogenated) } \\
\text { alkanes and cycloalkanes }\end{array}$ & $\begin{array}{l}\text { Methylobacter sp., } \\
\text { Methylococcus sp., } \\
\text { Methylocystis sp. }\end{array}$ & [75] \\
\hline
\end{tabular}




\begin{tabular}{l|l|l|l} 
An enzyme (s) & $\mathbf{P A H}(\mathbf{s})$ & $\begin{array}{l}\text { Degrading } \\
\text { microorganisms }\end{array}$ & Reference \\
\hline AlkB related alkane hydroxylases & $\begin{array}{l}\mathrm{C}_{5}-\mathrm{C}_{16} \text { alkanes, fatty acids, } \\
\text { alkylbenzenes, } \\
\text { cycloalkanes }\end{array}$ & $\begin{array}{l}\text { Pseudomonas sp,. } \\
\text { Burkholderia sp,. } \\
\text { Rhodococcus sp., } \\
\text { Mycobacterium sp. }\end{array}$
\end{tabular}

\section{Conclusion}

In this review, the availability of various analytical equipment to find and determine the amount of biosurfactant produced. A small number of organisms in the endemic microbial flora participate in biosurfactant production in nature to adapt to a variety of harmful conditions. The necessity of biosurfactant purification depends on its applications. For instance, if surfactants are used for environmental remediation, the ultimate yield should be microbial load-free, but at the expense of product quality. For cosmetic and pharmaceutical applications, however, biosurfactants must satisfy different regulatory standards. To heighten biosurfactants for industrial yield remains a challenge. Identifying efficient and significant surfactants is of paramount importance for industrial scale-up because the final yield compound is influenced by nutrients, microorganisms, micronutrients, and environmental factors. To exploit microorganisms in industry, it needs to further understand microbial genetics and physiology.

\section{Funding}

This research received no external funding.

\section{Acknowledgments}

We thank all colleagues.

\section{Conflicts of Interest}

The authors declare no conflict of interest.

\section{References}

1. Banat, I.M.; Franzetti, A.; Gandolfi, I.; Bestetti, G.; Martinotti, M.G.; Fracchia, L.; Smyth, T.J.; Marchant, R. Microbial biosurfactants production, applications and future potential. Applied Microbiology and Biotechnology 2010, 87, 427-444, https://doi.org/10.1007/s00253-010-2589-0.

2. Patowary, K.; Patowary, R.; Kalita, M.C.; Deka, S. Characterization of biosurfactant produced during degradation of hydrocarbons using crude oil as sole source of carbon. Frontiers in microbiology 2017, 8, 279, https://doi.org/10.3389/fmicb.2017.00279.

3. Dichiarante, V.; Milani, R.; Metrangolo, P. Natural surfactants towards a more sustainable fluorine chemistry. Green Chemistry 2018, 20, 13-27, https://doi.org/10.1039/C7GC03081A.

4. Jiménez-Peñalver, P.; Castillejos, M.; Koh, A.; Gross, R.; Sánchez, A.; Font, X.; Gea, T. Production and characterization of sophorolipids from stearic acid by solid-state fermentation, a cleaner alternative to chemical surfactants. Journal of cleaner production 2018, 172, 2735-2747, https://doi.org/10.1016/j.jclepro.2017.11.138.

5. Karlapudi, A.; Venkateswarulu, T.; Tammineedi, J.; Kanumuri, L.; Ravuru, B. Role of biosurfactants in bioremediation of oil pollutiona review. Petroleum 2018, 4, 241-249, https://doi.org/10.1016/j.petlm.2018.03.007. 
6. Lee, D.W.; Lee, H.; Kwon, B.-O.; Khim, J.S.; Yim, U.H.; Kim, B.S.; Kim, J.-J. Biosurfactant-assisted bioremediation of crude oil by indigenous bacteria isolated from Taean beach sediment. Environmental pollution 2018, 241, 254-264.

7. Derguine-Mecheri, L.; Kebbouche-Gana, S.; Khemili-Talbi, S.; Djenane, D. Screening and biosurfactant/bioemulsifier production from a high-salt-tolerant halophilic Cryptococcus strain YLF isolated from crude oil. Journal of Petroleum Science and Engineering 2018, 162, 712-724, https://doi.org/10.1016/j.petrol.2017.10.088.

8. Alizadeh-Sani, M.; Hamishehkar, H.; Khezerlou, A.; Azizi-Lalabadi, M.; Azadi, Y.; Nattagh-Eshtivani, E.; Fasihi, M.; Ghavami, A.; Aynehchi, A.; Ehsani, A. Bioemulsifiers derived from microorganisms: Applications in the drug and food industry. Advanced pharmaceutical bulletin 2018, 8, 191-199, https://doi.org/10.15171/apb.2018.023.

9. Joye, S.; Kleindienst, S.; Peña-Montenegro, T.D. SnapShot: microbial hydrocarbon bioremediation. Cell 2018, 172, 1336-1336, https://doi.org/10.1016/j.cell.2018.02.059.

10. Gudiña, E.J.; Pereira, J.F.; Costa, R.; Evtuguin, D.V.; Coutinho, J.A.; Teixeira, J.A.; Rodrigues, L.R. Novel bioemulsifier produced by a Paenibacillus strain isolated from crude oil. Microbial cell factories 2015, 14, https://doi.org/10.1186/s12934-015-0197-5.

11. Geetha, S.; Banat, I.; Joshi, S. Biosurfactants: production and potential applications in microbial enhanced oil recovery (MEOR). Biocatal Agric Biotechnol 2018, 14, 23-32, https://doi.org/10.1016/j.bcab.2018.01.010.

12. Egbogah, E.O.; Dawe, R.A. Spontaneous emulsification aspect of enhanced oil recovery. Journal of Chemical Technology and Biotechnology. Chemical Technology 1985, 35, 132-144, https://doi.org/10.1002/jctb.5040350307.

13. Sena, H.H.; Sanches, M.A.; Rocha, D.F.S.; Segundo Filho, W.O.P.; de Souza, É.S.; de Souza, J.V.B. Production of biosurfactants by soil fungi isolated from the Amazon forest. International journal of microbiology 2018, 2018, 1-8, https://doi.org/10.1155/2018/5684261.

14. Paraszkiewicz, K.; Bernat, P.; Kuśmierska, A.; Chojniak, J.; Płaza, G. Structural identification of lipopeptide biosurfactants produced by Bacillus subtilis strains grown on the media obtained from renewable natural resources. Journal of environmental management 2018, 209, 65-70, https://doi.org/10.1016/j.jenvman.2017.12.033.

15. Tan, Y.N.; Li, Q. Microbial production of rhamnolipids using sugars as carbon sources. Microbial cell factories 2018, 17, https://doi.org/10.1186/s12934-018-0938-3.

16. Das, M.D. Application of biosurfactant produced by an adaptive strain of C. tropicalis MTCC230 in microbial enhanced oil recovery (MEOR) and removal of motor oil from contaminated sand and water. Journal of Petroleum Science and Engineering 2018, 170, 40-48, https://doi.org/10.1016/j.petrol.2018.06.034.

17. Bea, S.A.; Carrera, J.; Soler, J.; Ayora, C.; Saaltink, M. Simulation of remediation alternatives for a $137 \mathrm{Cs}$ contaminated soil. Radiochimica Acta 2004, 92, 827-833, https://doi.org/10.1524/ract.92.9.827.54981.

18. Siebenhaller, S.; Hajek, T.; Muhle-Goll, C.; Himmelsbach, M.; Luy, B.; Kirschhöfer, F.; Brenner-Weiß, G.; Hahn, T.; Zibek, S.; Syldatk, C. Beechwood carbohydrates for enzymatic synthesis of sustainable glycolipids. Bioresources and bioprocessing 2017, 4, https://doi.org/10.1186/s40643-017-0155-7.

19. Gomes, M.B.; Gonzales-Limache, E.E.; Sousa, S.T.P.; Dellagnezze, B.M.; Sartoratto, A.; Silva, L.C.F.; Gieg, L.M.; Valoni, E.; Souza, R.S.; Torres, A.P.R.; Sousa, M.P.; De Paula, S.O.; Silva, C.C.; Oliveira, V.M. Exploring the potential of halophilic bacteria from oil terminal environments for biosurfactant production and hydrocarbon degradation under high-salinity conditions. International Biodeterioration \& Biodegradation 2018, 126, 231-242, https://doi.org/10.1016/j.ibiod.2016.08.014.

20. Kubicki, S.; Bollinger, A.; Katzke, N.; Jaeger, K.-E.; Loeschcke, A.; Thies, S. Marine biosurfactants: biosynthesis, structural diversity and biotechnological applications. Marine drugs 2019, 17, https://doi.org/10.3390/md17070408.

21. Joshi, S.J.; Al-Wahaibi, Y.M.; Al-Bahry, S.N.; Elshafie, A.E.; Al-Bemani, A.S.; Al-Bahri, A.; Al-Mandhari, M.S. Production, Characterization, and Application of Bacillus licheniformis W16 Biosurfactant in Enhancing Oil Recovery. Frontiers in Microbiology 2016, 7, https://doi.org/10.3389/fmicb.2016.01853.

22. Fenibo, E.O.; Ijoma, G.N.; Selvarajan, R.; Chikere, C.B. Microbial Surfactants: The Next Generation Multifunctional Biomolecules for Applications in the Petroleum Industry and Its Associated Environmental Remediation. Microorganisms 2019, 7, 581, https://doi.org/10.3390/microorganisms7110581.

23. Akbari, S.; Abdurahman, N.H.; Yunus, R.M.; Fayaz, F.; Alara, O.R. Biosurfactants -a new frontier for social and environmental safety: a mini review. Biotechnology Research and Innovation 2018, 2, 81-90, https://doi.org/10.1016/j.biori.2018.09.001.

24. Sharma, D.; Ansari, M.J.; Gupta, S.; Al Ghamdi, A.; Pruthi, P.; Pruthi, V. Structural Characterization and Antimicrobial Activity of a Biosurfactant Obtained From Bacillus pumilus DSVP18 Grown on Potato Peels. Jundishapur Journal of Microbiology 2015, 8, https://doi.org/10.5812/jjm.21257.

25. Vijayakumar, S.; Saravanan, V. Biosurfactants-types, sources and applications. Research Journal of Microbiology 2015, 10, 181-192, http://dx.doi.org/10.3923/jm.2015.181.192. 
26. Campos, J.M.; Montenegro Stamford, T.L.; Sarubbo, L.A.; de Luna, J.M.; Rufino, R.D.; Banat, I.M. Microbial biosurfactants as additives for food industries. Biotechnology Progress 2013, 29, 1097-1108, https://doi.org/10.1002/btpr.1796.

27. Ghosal, D.; Ghosh, S.; Dutta, T.K.; Ahn, Y. Current State of Knowledge in Microbial Degradation of Polycyclic Aromatic Hydrocarbons (PAHs): A Review. Frontiers in Microbiology 2016, 7, https://doi.org/10.3389/fmicb.2016.01369.

28. Gudiña, E.J.; Rodrigues, A.I.; Rodrigues, L.R.; Teixeira, J.A. Biosurfactants: production, applications and future potential. Applied Microbiology and Biotechnology 2017, 87, 427-444.

29. Nikolova, C.; Gutierrez, T. Use of microorganisms in the recovery of oil from recalcitrant oil reservoirs: Current state of knowledge, technological advances and future perspectives. Frontiers in Microbiology 2020, 10, https://doi.org/10.3389/fmicb.2019.02996.

30. Almatawah, Q. An Indigenous Biosurfactant Producing Burkholderia cepacia with High Emulsification Potential towards Crude Oil. Journal of Environmental \& Analytical Toxicology 2017, 7, 528, https://doi.org/10.4172/2161-0525.1000528.

31. Ghasemi, A.; Moosavi-Nasab, M.; Setoodeh, P.; Mesbahi, G.; Yousefi, G. Biosurfactant Production by Lactic Acid Bacterium Pediococcus dextrinicus SHU1593 Grown on Different Carbon Sources: Strain Screening Followed by Product Characterization. Scientific Reports 2019, 9, https://doi.org/10.1038/s41598019-41589-0.

32. Banat, I.M.; Satpute, S.K.; Cameotra, S.S.; Patil, R.; Nyayanit, N.V. Cost effective technologies and renewable substrates for biosurfactants' production. Frontiers in microbiology 2014, 5, https://doi.org/10.3389/fmicb.2014.00697.

33. Kaskatepe, B.; Yildiz, S. Rhamnolipid Biosurfactants Produced by Pseudomonas Species. Brazilian Archives of Biology and Technology 2016, 59, https://doi.org/10.1590/1678-4324-2016160786.

34. Aftab, M.N.; Haq, I.-u.; Baig, S. Systematic mutagenesis method for enhanced production of bacitracin by Bacillus licheniformis mutant strain UV-MN-HN-6. Brazilian Journal of Microbiology 2012, 43, 78-88, https://doi.org/10.1590/s1517-83822012000100009.

35. Cameotra, R.M.S. An update on the use of unconventional substrates for biosurfactant production and their new applications. Applied Microbiology and Biotechnology 2002, 58, 428-434, https://doi.org/10.1007/s00253-001-0924-1.

36. Nitschke, M.; Ferraz, C.; Pastore, G.M. Selection of microorganisms for biosurfactant production using agroindustrial wastes. Brazilian Journal of Microbiology 2004, 35, 81-85, https://doi.org/10.1590/s151783822004000100013.

37. Fernández-Pérez, M.; Otero, C. Enzymatic synthesis of amide surfactants from ethanolamine. Enzyme and Microbial Technology 2001, 28, 527-536, https://doi.org/10.1016/s0141-0229(01)00293-9.

38. Ali, N.; Wang, F.; Xu, B.; Safdar, B.; Ullah, A.; Naveed, M.; Wang, C.; Rashid, M.T. Production and Application of Biosurfactant Produced by Bacillus licheniformis Ali5 in Enhanced Oil Recovery and Motor Oil Removal from Contaminated Sand. Molecules 2019, 24, https://doi.org/10.3390/molecules24244448.

39. Ochsner, U.A.; Reiser, J.; Fiechter, A.; Witholt, B. Production of Pseudomonas aeruginosa Rhamnolipid Biosurfactants in Heterologous Hosts. Applied and environmental microbiology 1995, 61, 3503-3506, https://doi.org/10.1128/aem.61.9.3503-3506.1995.

40. Raza, Z.A.; Rehman, A.; Khan, M.S.; Khalid, Z.M. Improved production of biosurfactant by a Pseudomonas aeruginosa mutant using vegetable oil refinery wastes. Biodegradation 2006, 18, 115-121, https://doi.org/10.1007/s10532-006-9047-9.

41. Ma, Y.; Galinski, E.A.; Grant, W.D.; Oren, A.; Ventosa, A. Halophiles 2010: life in saline environments. Applied And Environmental Microbiology 2010, 76, 6971-6981, https://doi.org/10.1128/AEM.01868-10.

42. Zolfaghar, M.; Amoozegar, M.A.; Khajeh, K.; Babavalian, H.; Tebyanian, H. Isolation and screening of extracellular anticancer enzymes from halophilic and halotolerant bacteria from different saline environments in Iran. Mol. Biol. Rep 2019, 46, 3275-3286, https://doi.org/10.1007/s11033-019-04787-7.

43. Didari, M.; Bagheri, M.; Amoozegar, M.A.; Bouzari, S.; Babavalian, H.; Tebyanian, H.; Hassanshahian, M.; Ventosa, A. Diversity of halophilic and halotolerant bacteria in the largest seasonal hypersaline lake (AranBidgol-Iran). J Environ Health Sci Engineer 2020, 36, https://doi.org/10.1007/s40201-020-00519-3.

44. Rezaeeyan, Z.; Safarpour, A.; Amoozegar, M.A.; Babavalian, H.; Tebyanian, H.; Shakeri, F. High carotenoid production by a halotolerant bacterium, Kocuria sp. strain QWT-12 and anticancer activity of its carotenoid. EXCLI Journal 2017, 16, 840-851, https://doi.org/10.17179/excli2017-218.

45. Kristiansen, T.B.; Hagemeister, J.J.; Grave, M.; Hellung-Larsen, P. Surface mediated death of unconditioned Tetrahymena cells: effect of physical parameters, growth factors, hormones, and surfactants. Journal of cellular physiology 1996, 169, 139-148, https://doi.org/10.1002/(SICI)1097-4652(199610)169:1<139::AIDJCP14>3.0.CO;2-8.

46. Corti Monzón, G.; Nisenbaum, M.; Herrera Seitz, M.K.; Murialdo, S.E. New Findings on Aromatic Compounds' Degradation and Their Metabolic Pathways, the Biosurfactant Production and Motility of the Halophilic Bacterium Halomonas sp. KHS3. Current Microbiology 2018, 75, 1108-1118, https://doi.org/10.1007/s00284-018-1497-x. 
47. Zarparvar, P.; Amoozegar, M.A.; Babavalian, H.; Reza, F.M.; Tebyanian, H.; Shakeri, F. Isolation and identification of culturable halophilic bacteria with producing hydrolytic enzyme from Incheh Broun hypersaline wetland in Iran. Cell Mol Biol (Noisy-le-grand) 2016, 62, 31-36.

48. Perfumo, A.; Banat, I.M.; Marchant, R. Going Green and Cold: Biosurfactants from Low-Temperature Environments to Biotechnology Applications. Trends in Biotechnology 2018, 36, 277-289, https://doi.org/10.1016/j.tibtech.2017.10.016.

49. Corral, P.; Amoozegar, M.A.; Ventosa, A. Halophiles and Their Biomolecules: Recent Advances and Future Applications in Biomedicine. Marine Drugs 2020, 18, https://doi.org/10.3390/md18010033.

50. Rodrigues, E.M.; Morais, D.K.; Pylro, V.S.; Redmile-Gordon, M.; de Oliveira, J.A.; Roesch, L.F.W.; Cesar, D.E.; Tótola, M.R. Aliphatic hydrocarbon enhances phenanthrene degradation by autochthonous prokaryotic communities from a pristine seawater. Microbial ecology 2018, 75, 688-700, https://doi.org/10.1007/s00248-017-1078-8.

51. Chen, X.; Yu, L.; Qiao, G.; Chen, G.-Q. Reprogramming Halomonas for industrial production of chemicals. Journal of Industrial Microbiology \& Biotechnology 2018, 45, 545-554, https://doi.org/10.1007/s10295018-2055-z.

52. Chuo, S.C.; Abd-Talib, N.; Mohd-Setapar, S.H.; Hassan, H.; Nasir, H.M.; Ahmad, A.; Lokhat, D.; Ashraf, G.M. Reverse micelle extraction of antibiotics using an eco-friendly sophorolipids biosurfactant. Scientific reports 2018, 8, 1-13, https://doi.org/10.1038/s41598-017-18279-w.

53. Badrul Hisham, N.H.; Ibrahim, M.F.; Ramli, N.; Abd-Aziz, S. Production of Biosurfactant Produced from Used Cooking Oil by Bacillus sp. HIP3 for Heavy Metals Removal. Molecules 2019, 24, https://doi.org/10.3390/molecules24142617.

54. Zhao, F.; Shi, R.; Ma, F.; Han, S.; Zhang, Y. Oxygen effects on rhamnolipids production by Pseudomonas aeruginosa. Microbial cell factories 2018, 17, https://doi.org/10.1186/s12934-018-0888-9.

55. Davin, M.; Starren, A.; Deleu, M.; Lognay, G.; Colinet, G.; Fauconnier, M.-L. Could saponins be used to enhance bioremediation of polycyclic aromatic hydrocarbons in aged-contaminated soils? Chemosphere 2018, 194, 414-421, https://doi.org/10.1016/j.chemosphere.2017.11.174.

56. Deary, M.E.; Ekumankama, C.C.; Cummings, S.P. Effect of lead, cadmium, and mercury co-contaminants on biodegradation in PAH-polluted soils. Land Degradation \& Development 2018, 29, 1583-1594, https://doi.org/10.1002/ldr.2958.

57. Rada, E.C.; Andreottola, G.; Istrate, I.A.; Viotti, P.; Conti, F.; Magaril, E.R. Remediation of soil polluted by organic compounds through chemical oxidation and phytoremediation combined with DCT. International journal of environmental research and public health 2019, 16, https://doi.org/10.3390/ijerph16173179.

58. Yalaoui-Guellal, D.; Brahmi, F.; Touati, A.; De Champs, C.; Banat, I.M.; Madani, K. Production of Biosurfactants by Hydrocarbons degrading bacteria isolated from Soummam watershed Sediments of Bejaia in Algeria. Environmental Progress \& Sustainable Energy 2017, 37, 189-195, https://doi.org/10.1002/ep.12653.

59. Sanchart, C.; Watthanasakphuban, N.; Boonseng, O.; Nguyen, T.-H.; Haltrich, D.; Maneerat, S. Tuna condensate as a promising low-cost substrate for glutamic acid and GABA formation using Candida rugosa and Lactobacillus futsaii. Process Biochemistry $2018, \quad 70, \quad 29-35$, https://doi.org/10.1016/j.procbio.2018.04.013.

60. Gao, Y.; Zheng, H.; Hu, N.; Hao, M.; Wu, Z. Technology of fermentation coupling with foam separation for improving the production of nisin using a $\kappa$-carrageenan with loofa sponges matrix and an hourglass-shaped column. Biochemical Engineering Journal 2018, 133, 140-148, https://doi.org/10.1016/j.bej.2018.02.008.

61. Gomes, M.; Gonzales-Limache, E.; Sousa, S.; Dellagnezze, B.; Sartoratto, A.; Silva, L.; Gieg, L.; Valoni, E.; Souza, R.; Torres, A. Exploring the potential of halophilic bacteria from oil terminal environments for biosurfactant production and hydrocarbon degradation under high-salinity conditions. International Biodeterioration \& Biodegradation 2018, 126, 231-242, https://doi.org/10.1016/j.ibiod.2016.08.014.

62. Ostrem Loss, E.M.; Yu, J.-H. Bioremediation and microbial metabolism of benzo(a)pyrene. Molecular Microbiology 2018, 109, 433-444, https://doi.org/10.1111/mmi.14062.

63. Vasudevan, V.; Gayathri, K.V.; Krishnan, M.E.G. Bioremediation of a pentacyclic PAH, Dibenz(a,h)Anthracene- A long road to trip with bacteria, fungi, autotrophic eukaryotes and surprises. Chemosphere 2018, 202, 387-399, https://doi.org/10.1016/j.chemosphere.2018.03.074.

64. Arora, N.K.; Fatima, T.; Mishra, I.; Verma, M.; Mishra, J.; Mishra, V. Environmental sustainability: challenges and viable solutions. Environmental Sustainability 2018, 1, 309-340, https://doi.org/10.1007/s42398-018-00038-w.

65. Yang, R.; Liu, G.; Chen, T.; Li, S.; An, L.; Zhang, G.; Li, G.; Chang, S.; Zhang, W.; Chen, X.; Wu, X.; Zhang, B. Characterization of the genome of a Nocardia strain isolated from soils in the Qinghai-Tibetan Plateau that specifically degrades crude oil and of this biodegradation. Genomics 2019, 111, 356-366, https://doi.org/10.1016/j.ygeno.2018.02.010.

66. Fan, F.; Zhang, B.; Morrill, Penny L.; Husain, T. Isolation of nitrate-reducing bacteria from an offshore reservoir and the associated biosurfactant production. RSC Advances 2018, 8, 26596-26609, https://doi.org/10.1039/c8ra03377c. 
67. Nzila, A. Biodegradation of high-molecular-weight polycyclic aromatic hydrocarbons under anaerobic conditions: Overview of studies, proposed pathways and future perspectives. Environmental Pollution 2018, 239, 788-802, https://doi.org/10.1016/j.envpol.2018.04.074.

68. Ostrem Loss, E.M.; Yu, J.H. Bioremediation and microbial metabolism of benzo (a) pyrene. Molecular microbiology 2018, 109, 433-444, https://doi.org/10.1111/mmi.14062.

69. Haleyur, N.; Shahsavari, E.; Taha, M.; Khudur, L.S.; Koshlaf, E.; Osborn, A.M.; Ball, A.S. Assessing the degradation efficacy of native PAH-degrading bacteria from aged, weathered soils in an Australian former gasworks site. Geoderma 2018, 321, 110-117, https://doi.org/10.1016/j.geoderma.2018.02.004.

70. Saxena, G.; Kishor, R.; Purchase, D.; Bharagava, R.N. Phytoremediation of environmental pollutants. Environmental Earth Sciences 2019, 78, https://doi.org/10.1007/s12665-019-8454-2.

71. Yang, J.; Li, W.; Ng, T.B.; Deng, X.; Lin, J.; Ye, X. Laccases: Production, Expression Regulation, and Applications in Pharmaceutical Biodegradation. Frontiers in Microbiology 2017, 8, https://doi.org/10.3389/fmicb.2017.00832.

72. Charati, H.; Peng, M.-S.; Chen, W.; Yang, X.-Y.; Jabbari Ori, R.; Aghajanpour-Mir, M.; Esmailizadeh, A.; Zhang, Y.-P. The evolutionary genetics of lactase persistence in seven ethnic groups across the Iranian plateau. Human Genomics 2019, 13, https://doi.org/10.1186/s40246-019-0195-5.

73. Wong, K.-S.; Huang, Q.; Au, C.-H.; Wang, J.; Kwan, H.-S. Biodegradation of dyes and polyaromatic hydrocarbons by two allelic forms of Lentinula edodes laccase expressed from Pichia pastoris. Bioresource Technology 2012, 104, 157-164, https://doi.org/10.1016/j.biortech.2011.10.097.

74. McDonald, I.R.; Miguez, C.B.; Rogge, G.; Bourque, D.; Wendlandt, K.D.; Groleau, D.; Murrell, J.C. Diversity of soluble methane monooxygenase-containing methanotrophs isolated from polluted environments. FEMS Microbiology Letters 2006, 255, 225-232, https://doi.org/10.1111/j.15746968.2005.00090.x.

75. Sharma, S.; Tiwari, S.; Hasan, A.; Saxena, V.; Pandey, L.M. Recent advances in conventional and contemporary methods for remediation of heavy metal-contaminated soils. 3 Biotech 2018, 8, 216, https://doi.org/10.1007/s13205-018-1237-8.

76. Tribelli, P.M.; Rossi, L.; Ricardi, M.M.; Gomez-Lozano, M.; Molin, S.; Raiger Iustman, L.J.; Lopez, N.I. Microaerophilic alkane degradation in Pseudomonas extremaustralis: a transcriptomic and physiological approach. Journal of Industrial Microbiology \& Biotechnology 2017, 45, 15-23, https://doi.org/10.1007/s10295-017-1987-z.

77. Linda, A.; Hernado, P.B.; Yuewen, D. Response of microbial communities to oil spill in the Gulf of Mexico: A review. African Journal of Microbiology Research 2018, 12, 536-545, https://doi.org/10.5897/ajmr2018.8843.

78. Lodens, S.; De Graeve, M.; Roelants, S.L.; De Maeseneire, S.L.; Soetaert, W. Transformation of an exotic yeast species into a platform organism: a case study for engineering glycolipid production in the yeast Starmerella bombicola. Methods in molecular biology 2018, 1772, 95-123, https://doi.org/10.1007/978-14939-7795-6_5.

79. Mitra, A.; Mukhopadhyay, S. Biofilm mediated decontamination of pollutants from the environment. Aims Bioengineering 2016, 3, 44, https://doi.org/10.3934/bioeng.2016.1.44.

80. Muthukamalam, S.; Sivagangavathi, S.; Dhrishya, D.; Sudha Rani, S. Characterization of dioxygenases and biosurfactants produced by crude oil degrading soil bacteria. Brazilian Journal of Microbiology 2017, 48, 637-647, https://doi.org/10.1016/j.bjm.2017.02.007. 